\title{
Digitalization and Indian economy: patterns and questions
}

\author{
Inna Lazanyuk ${ }^{1, *}$, and Dr. Swati Modi ${ }^{2}$ \\ ${ }^{1}$ RUDN University, Miklukho-Maklaya str.6, 117198 Moscow, Russia \\ ${ }^{2}$ GLS Institute of Business Administration, GLS University, Opp. Law Garden, Ellisbridge, 380006 \\ Ahmedabad, India
}

\begin{abstract}
Digital technologies play a crucial role in enhancing the competitiveness of the economy and promoting economic growth in many countries. The paper is dedicated to the development of digitalization in the modern economy of India and its impact on economic processes that determine the country's economic growth. We analyzed changes in unemployment, debit and credit card transactions, indirect tax revenues, exports, and trade volumes. In this work, we used analysis and methods of correlation-regression analysis. We found a positive relationship between the number of debit and credit card transactions for indirect tax collection. We confirmed that digitalization had influenced the growth of exports and trade volumes by increasing the role of e-commerce while not increasing the unemployment rate.
\end{abstract}

\section{Introduction}

Digitalization, being an objective process, affects all spheres of the socio-economic system. Modern information technologies have a significant impact on the economy and society, changing the prevailing economic structure and life of people.A study by the McKinsey Global Institute (MGI) notes that in 2017 the digital revolution entered a decisive phase every second inhabitant of the Earth connected to the Internet.

UNCTAD's 2017 Report on the New Digital Economy and Development notes that it is challenging to measure the development impact of digital growth due to its rapidly changing nature and complex network of areas affected by the growth of the ICT sector. However, the study looks at a wide range of impact areas such as economic performance, employment, innovation (including research and development), privacy and security, education, health, citizen, individual and community participation, and the environment.

Since July 2015, the Make India Digital project launched in India. This project aims to increase the digital literacy of rural India by connecting them to the Internet. India is one of the fastest-growing countries with a very high youth population $(\sim 65 \%)$, less than 35 years old.The impact of digitalization can only clearly be observed when people can understand and accept them. Every person must be financially literate, and this makes it possible to make intelligent decisions. After introducing digitalization, financial transactions began to be

\footnotetext{
*Corresponding author: lazanyuk-iv@rudn.ru
} 
carried out over the Internet, and digital financial literacy became critical. Digitalization can transform the business model and provide new opportunities for generating revenue and creating value.

Despite the active study of various economic processes by scientists from different countries, many unsolved problems exist. As a rule, research in this area involves studying the decline in employment due to the introduction of new technologies. At the same time, this issue looks pretty relevant given the high rate of destructive processes. American scientists have found that almost half of the workers are engaged in operations that new technologies and machines can potentially replace within one to two decades [1]. A similar study in Germany estimated the share of such workers at $42 \%$ [2]. The work of scientists from India, the digital divide issues, and the impact of digitization on the distribution of income and wage inequality $[3,4]$. However, one should not consider only the negative aspects of this process. The advantages include the increase in labor mobility [5] due to the "blurring" the boundaries, opening up new opportunities and contributes to competitiveness.

For the first time, the term digital economy was used in 1995 by Canadian professor D. Tapscott in his book "Digital Economy: Promise and Danger in the Age of Network Intelligence" [6]. American scientist J. Negroponte drew attention to the role of information and digital technologies in the economy and society and their possible increasing importance in the future [7]. Since its first appearance in the mid-1990s, the definition of the digital economy has evolved to reflect the rapidly changing nature of technology and its use by businesses and consumers [8].The scientific literature focuses primarily on the current state and prospects for the development of digitalization of the economy [9]. Some authors emphasize the role and significance of transaction costs for digital business [10], others cover the issues of risk and the limitations that result from innovations of the digital economy, leading to social problems [11]. Some authors explore the development and analysis of business models in today's economy [12-14]. Currently, the research quite widely presents the general problems of business development and management in the conditions of a sharing economy $[15,16]$. The sharing economy is based on information technology to provide people with information to optimize resources by moving surplus goods and services [17, 18]. However, research is under-represented on the contribution of the digitization of the economy on economic growth and the level of social welfare, primarily since the acceleration of these processes has not led to the rapid development of individual countries and the world economy a whole.

This paper focuses on the impact of accelerated digitalization on the Indian economy. The presented research is based on analyzing two main hypotheses: does digitalization reduce the level of employment in the Indian economy; whether debit and credit card transactions affect indirect tax revenue collection, export growth, and trade volumes. We are interested in why digitalization is essential and which sectors have been affected and how India could become the third-largest economy shortly. The work aims to identify the contribution of digitalization to the Indian economy in sustainable development.

\section{Methods}

The research methodology is based on secondary data analysis. Secondary data we collected from reliable government sources, research papers from prominent researchers, websites, journals, etc. The study also involves recognizing the challenges and opportunities of digital India in all aspects of excellence and improving the personal satisfaction of residents. The study provides an optimistic methodology for providing broader job prospects for youth to help the country's economy achieve positive growth. 


\section{Results and Discussion}

The research literature describes the significant contribution that digitalization has made to economic growth and productivity growth and efficiency at the macroeconomic and microeconomic levels. While the overall conclusion is clear, the results vary widely, and the precise definition or quantification of effects is complex for many reasons. First, digitalization is one of the many drivers of productive activity, so it isn't easy to measure its impact on outcomes such as GDP or jobs. Moreover, digitalization contributes to production in many ways - by increasing the efficiency of other resources, such as the workforce (for example, by allowing skilled workers to shift their attention from routine tasks to more complex tasks, thereby increasing labor productivity, capital (for example, allowing more flexibility redirecting excess capacity to produce goods for other markets); and changing fundamental ways of using resources (for example, by enabling businesses to reorganize).

\subsection{New digital realities}

The Government's efforts facilitated shaping new digital realities in India, active actions of Indian business, and joint steps of Indian government agencies and private entrepreneurs. In 2015, India launched the campaign "Digital India» (Digital India), which included some critical government initiatives to enhance digital literacy, infrastructure development, and the creation of e-Government. Among the most significant successes achieved along this path is the completion of the design and implementation of the state system of digital identification of citizens "Adhar". An important step was creating a single digital tax system, extended to all states that previously had individual tax rules.

The spread of digital technologies in agriculture, education, energy efficiency, employment and labor market regulation, etc. is essential for the country and has significant potential. There is a widespread belief that the introduction of new technologies leads to a decrease in employment.

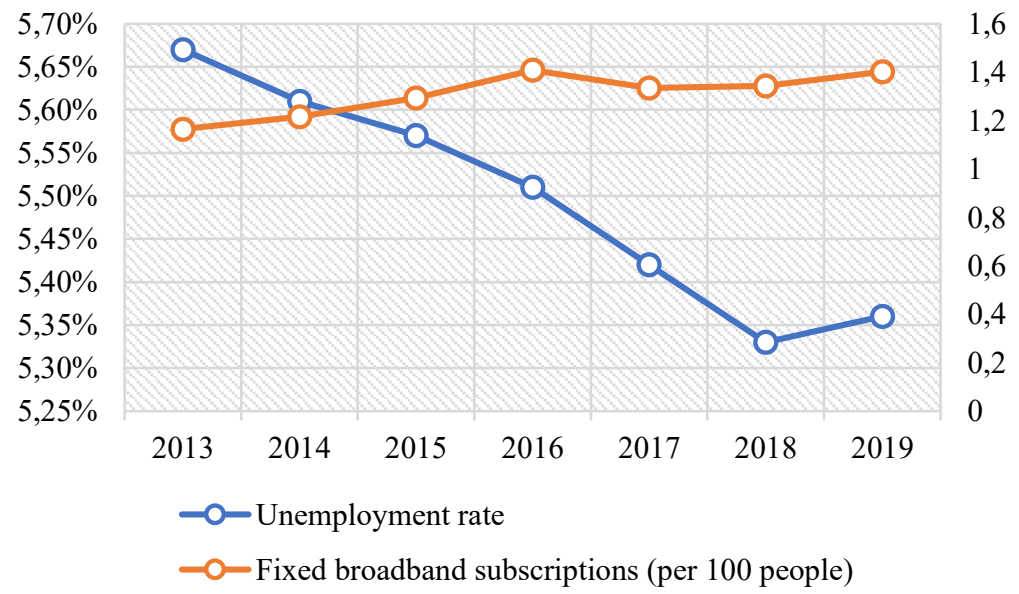

Fig. 1. Unemployment rate (left axis), Fixed broadband subscriptions (right axis) [19].

During the study period from 2013 to 2020 , the number of broadband subscribers in India grew by an average of $20 \%$. Fig. 1, you can see that the unemployment rate since 2013 declines and the number of subscribers continues to grow. It indicates that with an increase in the number of broadband subscribers, unemployment decreases, positively impacting digitalization. It does not support the hypothesis that digitalization leads to a decrease in 
employment. Instead, it leads to a redistribution of work due to, for example, an increase in employment in large infrastructure projects, etc.

The development and implementation of the fast payment system by the Reserve Bank of India and the Association of Indian Banks led in the shortest possible time (only 5-7 years) to revolutionary changes in such industries as electronic payments and Fintech, e-commerce, telemedicine, entertainment. Debit and credit card transactions are sky rocketing (Fig.2)

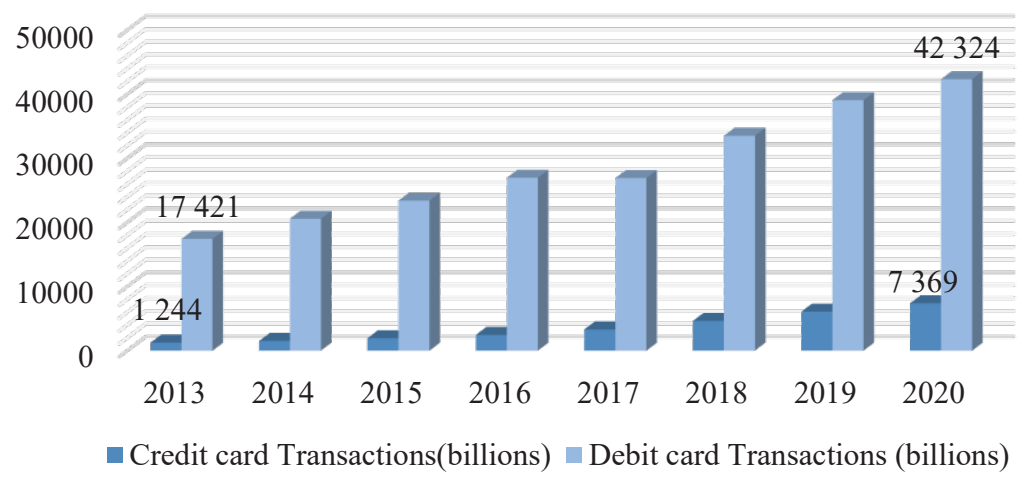

Fig. 2. The number of Card Transactions Source: Prowess Database

As seen in Fig. 2 for the period 2013-2020, the number of debit card transactions increased by an average of 2.5 times. It is also expanding the number of credit card transactions, the annual growth during the same period amounted to $28.9 \%$.

The e-commerce market volume has grown almost 5 times compared to 2015 and in 2020 amounted to 64 billion US dollars. Due to the growth of Internet users, which in 2020 reached 697 million people and the number of mobile phones sold (3.6 billion units). The Indian ecommerce market is overgrowing and is projected to exceed $\$ 100$ billion by 2023 .

In just a few years, India has made a quantum leap in many areas related to digitalization, avoiding the intermediate stages that other countries have spent years on, and second only to Indonesia in the speed of this process. Data consumption per user in India is growing twice as fast as in the United States and China, increasing 152\% annually. Internet users in India are expected to increase by about $40 \%$ to $750-800$ million by 2023 , and the number of smartphones will double to 650-700 million. With a high degree of confidence, we can assume that the new conditions associated with a pandemic significantly speed up these processes. Over the past few years, India has gone through a rapid digitalization journey. The current crisis has dramatically accelerated this process and also more noticeably indicated specific trends.

\subsection{Correlation and regression analysis of the impact of digitalization in the country's economy}

More than 560million internet users in 2020, India has become the second largest online market globally. The accessibility to internet facilities is increasing day by day. The government efforts towards digitalization have resulted in the increase in country's digital population amounting to approximately 688 million active users as of January 2020. The effect of digitalization in India has been pronounced and positive. In this study, the impact of digitalization has been studied on the unemployment rate, debit and credit card transactions, Indirect tax revenue collection, level of exports and trading volumes. 
Table 1. Correlation Matrix between factors.

\begin{tabular}{|l|r|r|r|}
\hline Corelation Matrix table No 1 & internet usage ( millions) & Trading volumes & Indirect tax revenue (Millions) \\
\hline internet usage ( millions) & 1 & & \\
\hline Trading volumes & 0.218386547 & 1 & \\
\hline Indirect tax revenue ( Million & 0.981960691 & 0.363486324 & \\
\hline
\end{tabular}

We can infer that internet usage is highly significantly and positively related with indirect tax revenue $(0.98)$ from the table 1 . The trading volumes have increased due to digitalization and technology advancement. The E-trading helps investor to access the market easily and also increases their awareness. Due to the modernization of Indian stock market, especially online trading, the trading volumes have increased. There is a significant positive relationship between internet usage and trading volumes, indicating the up surge of activity in the stock market due to digitalization.

Table 2. Regression statistics results.

\begin{tabular}{|c|c|c|c|c|c|c|c|}
\hline \multicolumn{8}{|c|}{ Regression Statistics } \\
\hline Multiple R & 0.981961 & & & & & & \\
\hline R Square & 0.964247 & & & & & & \\
\hline $\begin{array}{l}\text { Adjusted R } \\
\text { Square }\end{array}$ & 0.958288 & & & & & & \\
\hline $\begin{array}{l}\text { Standard } \\
\text { Error }\end{array}$ & 1015463 & & & & & & \\
\hline $\begin{array}{l}\text { Observation } \\
\mathrm{S}\end{array}$ & 8 & & & & & & \\
\hline \multicolumn{8}{|l|}{ ANOVA } \\
\hline & $d f$ & $S S$ & $M S$ & $F$ & $\begin{array}{c}\text { Significance } \\
F\end{array}$ & & \\
\hline Regression & 1 & $1.7 \mathrm{E}+14$ & $1.7 \mathrm{E}+14$ & 161.817 & $1.4 \mathrm{E}-05$ & & \\
\hline Residual & 6 & $6.2 \mathrm{E}+12$ & $1 \mathrm{E}+12$ & & & & \\
\hline \multirow[t]{2}{*}{ Total } & 7 & $1.7 \mathrm{E}+14$ & & & & & \\
\hline & Coefficients & $\begin{array}{l}\text { Standard } \\
\text { Error }\end{array}$ & $t$ Stat & $P$-value & Lower 95\% & $\begin{array}{c}\text { Upper } \\
95 \%\end{array}$ & $\begin{array}{l}\text { Lower } \\
95.0 \%\end{array}$ \\
\hline Intercept & 3183935 & 1085234 & 2.93387 & 0.02616 & 528463 & 5839407 & 528463 \\
\hline $\begin{array}{l}\text { internet } \\
\text { usage } \\
\text { (millions) }\end{array}$ & 30081.15 & 2364.73 & 12.7207 & $1.4 \mathrm{E}-05$ & 24294.9 & 35867.4 & $\begin{array}{r}24294 . \\
9\end{array}$ \\
\hline
\end{tabular}

The model is highly significant (Tab. 2) The Null hypothesis that the tax revenue is not depending on the internet usage is rejected. There has been a tremendous and significant relationship between the two variables. The collection of Indirect Tax revenue has increased considerably due to the better internet facilities and other IT development initiatives by the Indian Government.

Table 3. Correlation Matrix between factors.

\begin{tabular}{|l|l|l|l|l|l|l|}
\hline Correlation Matrix & $\begin{array}{l}\text { Fixed broadband } \\
\text { subscriptions } \\
\text { (per 100 people) } \\
\text { India }\end{array}$ & $\begin{array}{l}\text { Unemployment } \\
\text { rate }\end{array}$ & $\begin{array}{l}\text { Credit card } \\
\text { transactions }\end{array}$ & $\begin{array}{l}\text { Debit } \\
\text { card } \\
\text { transactio } \\
\text { ns }\end{array}$ & $\begin{array}{l}\text { Transa } \\
\text { ctions } \\
\text { at POS }\end{array}$ & $\begin{array}{l}\text { Exports } \\
\text { (Millions } \\
\text { ) }\end{array}$ \\
\hline $\begin{array}{l}\text { Fixed broadband } \\
\text { subscriptions (per } \\
100 \text { people) India }\end{array}$ & 1 & & & & & \\
\hline Unemployment rate & -0.784 & 1 & & & & \\
\hline $\begin{array}{l}\text { Credit card } \\
\text { transactions }\end{array}$ & 0.721 & -0.921 & 1 & & & \\
\hline
\end{tabular}


Table 3. Continued.

\begin{tabular}{|l|l|l|l|l|l|l|}
\hline $\begin{array}{l}\text { Debit card } \\
\text { transactions }\end{array}$ & 0.826 & -0.928 & 0.979 & 1 & & \\
\hline Transactions at POS & 0.666 & -0.927 & 0.992 & 0.954 & 1 & \\
\hline Exports (Millions) & 0.702 & -0.790 & 0.855 & 0.884 & 0.833 & 1 \\
\hline
\end{tabular}

The Unemployment rate has a negative correlation which clearly states with the increase in broadband subscriptions, the unemployment is reducing which is a positive impact of digitalization (Tab. 3). There is a significant direct positive relationship between fixed broadband subscriptions per 100 people with credit card transactions, debit card transactions, transactions at POS and exports. There has been a significant increase in credit card transactions by $388.35 \%$, in debit card transactions by $124.14 \%$, transactions at POS by $699.42 \%$ and in level of exports by $68.88 \%$.

Table 4. Regression statistics results.

\begin{tabular}{|c|c|c|c|c|c|c|}
\hline \multicolumn{2}{|c|}{ Regression Statistics } & & & & & \\
\hline Multiple R & 0.784981 & & & & & \\
\hline R Square & 0.616196 & & & & & \\
\hline $\begin{array}{l}\text { Adjusted R } \\
\text { Square }\end{array}$ & 0.539435 & & & & & \\
\hline Standard Error & 0.00088 & & & & & \\
\hline Observations & 7 & & & & & \\
\hline \multicolumn{7}{|l|}{ ANOVA } \\
\hline & $d f$ & $S S$ & $M S$ & $F$ & $\begin{array}{l}\text { Significance } \\
F\end{array}$ & \\
\hline Regression & 1 & $6.21 \mathrm{E}-06$ & $\begin{array}{l}6.21 \mathrm{E}- \\
06\end{array}$ & 8.02748 & 0.036534 & \\
\hline Residual & 5 & $3.87 \mathrm{E}-06$ & $\begin{array}{l}7.74 \mathrm{E}- \\
07\end{array}$ & & & \\
\hline \multirow[t]{2}{*}{ Total } & 6 & $1.01 \mathrm{E}-05$ & & & & \\
\hline & $\begin{array}{l}\text { Coefficien } \\
\text { ts }\end{array}$ & $\begin{array}{l}\text { Standard } \\
\text { Error }\end{array}$ & $t$ Stat & $P$-value & Lower 95\% & $\begin{array}{l}\text { Upper } \\
95 \%\end{array}$ \\
\hline Intercept & 0.069 & 0.0051 & $\begin{array}{l}13.4679 \\
9\end{array}$ & $\begin{array}{l}4.04 \mathrm{E}- \\
05\end{array}$ & 0.056284 & 0.082837 \\
\hline $\begin{array}{l}\text { Fixed } \\
\text { broadband } \\
\text { subscriptions } \\
\text { (per } 100 \text { people) } \\
\text { India }\end{array}$ & -0.01116 & 0.003938 & -2.833 & 0.03653 & -0.02128 & -0.00103 \\
\hline
\end{tabular}

Regression model of fixed broad band subscription and unemployment rate where unemployment is a dependent variable on fixed broad band subscription (Tab. 4). The model is significant and the unemployment rate is decreasing with the increase in fixed broad band subscription. Individuals using the Internet (\% of population) in India have increased from $15.1 \%$ to $20.08 \%$

India is going for mass vaccination where lakhs of people are vaccinated per day. As soon as the vaccination is done, message is sent that you are partially or fully vaccinated. Maintaining of such huge database with all the details like registration, date of first dose, 2nd dose is all made possible through digitalization.

Indian E-commerce is overgrowing and is expected to go beyond the US economy by 2034. India e-commerce sector will reach US $\$ 99$ billion by 2024 from US $\$ 30$ billion in 2019 , 
expanding at a $27 \%$ CAGR, with grocery and fashion/apparel likely to be the key drivers of incremental growth. There has been increase in Internet and smart phone penetration. Due to these various developments in November 2020, Amazon India announced collaboration with Hindustan Petroleum Corporation Limited. Under this partnership, customers will be able to book and pay for their LPG cylinders until the delivery. Amazon India also collaborated with the Indian Railway Catering and Tourism Corporation (IRCTC) to enable users to book and reserve train tickets on Amazon. Amazon India invested over Rs. 700 crores (US\$ 95.40 million) into its payment unit, Amazon Pay. Market size of e-commerce industry (Billion) has grown from $14 \%$ in 2014 to $64 \%$ in 2020 .

Table 5. Correlation Matrix between factors

\begin{tabular}{|l|r|r|}
\hline \multicolumn{1}{|c|}{ Correlation Matrix } & Secure Internet servers - India & GVA at basic prices \\
\hline Secure Internet servers - India & 1 & \\
\hline GVA at basic prices & 0.897972408 & 1 \\
\hline
\end{tabular}

From the table 5 we can infer that Gross Value added at basic prices is highly correlated with the secure internet servers which are a clear indication that the increasing use of Internet is having a positive association with GVA [20].

\section{Conclusion}

The study showed evidence of the contribution of digitalization to the Indian economy. The hypothesis that connecting users to broadband increases the unemployment rate has not been confirmed. Use of smart phones affected digital transactions and increased transparency and accountability of the financial system. We reaffirm the importance of financial literacy, which can change the development phase of emerging economies such as India. Internet use is highly and positively associated with indirect tax revenue. Due to the modernization of the Indian stock market, especially online trading, trading volumes have increased. There is a significant positive relationship between Internet usage and trading volumes, indicating a surge in stock market activity due to digitalization.

The current crisis associated with the pandemic is shaping new consumer habits and increasing the demand for qualitative changes in approaches to economic development problems for many countries of the world in the future. Correct implementation of digitalization could change the development phase of the Indian economy and enable it to become the third-largest economy in the future.

\section{References}

1. C. Frey, M. Osborne, Technological Forecasting and Social Change, 114, 254 (2017)

2. M. Arntz, T. Gregory, U. Zierahn, SSRN Electronic Journal (2019)

3. R. Kapoor, Technology, Accelerators of India's Growth-Industry, Trade and Employment, 301 (Springer, Singapore, 2020)

4. D. Maiti, F. Castellacci, A. Melchior, Digitalisation and Development, 3 (Springer, Singapore, 2020)

5. H. Matlay, Journal of Small Business and Enterprise Development, 11(3), 419 (2004)

6. R. Yakob, International Journal of Advertising, 28(1), 182 (2009)

7. N. Negroponte, R. Harrington, S. McKay, W Christian, Computers in Physics, 11(3), 261 (1997) 
8. K. Barefoot, D. Curtis, W. Jolliff, J. R. Nicholson, R. Omohundro, US Department of Commerce Bureau of Economic Analysis, Washington, DC, 15 (2018)

9. K. Schwab, The Fourth Industrial Revolution: What It Means and How to Respond (2015) https://www.foreignaffairs.com

10. M. Munger, Journal of Economic Sociology, 20(5), 74 (2019)

11. D. Curran, European journal of social theory, 21(2), 207 (2018)

12. B. W. Wirtz, Digital business models (Springer International Publishing, 2019)

13. D. Stojanovic, Economics: theory and practice,10(1), 80 (2017)

14. H. Ke, S. Chai, R. Cheng, Journal of Intelligent \& Fuzzy Systems, 36(1), 609 (2019)

15. S. Revinova, S. Ratner, I. Lazanyuk, K. Gomonov, Sustainability, 12(12), 4855 (2020)

16. W., Nadeem, M. Juntunen, F. Shirazi, N. Hajli, Technological Forecasting and Social Change, 151, 119786 (2020)

17. B. Fang, Q. Ye, R. Law, Annals of Tourism Research, 57, 264 (2016)

18. S. Hofmann, O. Sæbø, A.M. Braccini, S. Za, Government Information Quarterly, 36(4), 101399 (2019)

19. India: Internet subscribers, per 100 people, https://www.theglobaleconomy.com

20. Indian E-commerce Industry Analysis (2021) https://www.ibef.org 